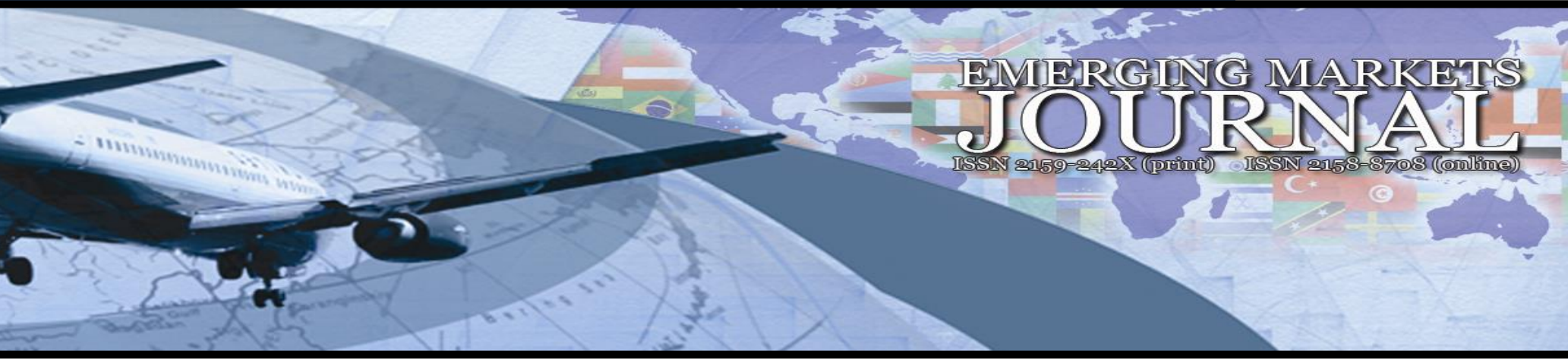

\title{
Re-examining Firm Size and Corporate Social Responsibility: The Visibility Approach
}

\section{Golrida Karyawati P}

Universitas Prasetiya Mulya, Indonesia | golridda@yahoo.com

\author{
Mira Muliani \\ KPMG Indonesia, Indonesia | mira.muliani@ outlook.com
}

\section{Prem Lal Joshi}

Multimedia University, Malaysia I prem@acadjoshi.com

Volume 9 No 1 (2019) ｜ ISSN 2158-8708 (online) | DOI 10.5195/emaj.2019.160 | http://emaj.pitt.edu |

\begin{abstract}
In a previous study on the firm size and corporate social responsibility (CSR) participation conducted by Golrida, et al (2017), different result is reported with Udayasankar's hypothesis (2008) which states a U-shape relationship of firm size and CSR participation. However, it is arqued that Udayasankar hyppothesis is better applicable in developed countries, while in developing countries an inverted - U shape relationship is found. But, Golrida et al (2017) can only prove the form of relationship using two perspectives stated by Udayasankar, which are operating scale and resourcess access. The proxy of visibility could not capture the inverted $U$ shape relationship due to measurement problem in the previous study. This study aims at re-examining the relationship between firm size and CSR participation from the visibility perpective by employing two proxies of visibility, which are analyst coverage and news coverage respectively. Indonesian companies are chosen to capture the context of developing country. Content analysis is done in obtaining CSR data of 433 companies listed on Indonesian Stock Exchange on 2012, while the data of visibility proxies are extracted from Thomson Reuters and selected news portal namely, Detik.com. The result of study shows that both visibility proxies, which are Analysts Coverage and Media Coverage form inverted U- shape relationship with CSR participation. The findings in this study contribute to the literature that, the form of firm size and CSR participation relationship in the context of developing countries is different than those in developed countries.
\end{abstract}

Keywords: CSR Participation, Firm Size, Visibility, Analyst Coverage, News Coverage

\section{$(\mathrm{cc}) \mathrm{EY}$}

New articles in this journal are licensed under a Creative Commons Attribution 3.0 United States License.

\section{ULIS D-Sent?}

This journal is published by the University Library System of the University of Pittsburgh as part

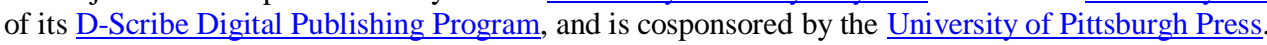




\section{Re-examining Firm Size and Corporate Social Responsibility: The Visibility Approach}

\section{Golrida Karyawati P \\ Mira Muliani \\ Prem Lal Joshi}

\section{Background}

This research emphasizes the importance of country characteristics in analyzing the relationship between firm size and CSR participation. The previous research show the inconsistent relationship between firm size and CSR participation. Gamrh \& Dhammari (2016), Tan et al (2016), Shubiri et al (2012), Gamerschlag et al (2011), and Darnall et al (2009), for example, found a positive relationship between firm size and CSR participantion. On the other hand, Ebiringa et al (2013) and Nawaiseh et al (2015) indicated a negative relationship between the two variables. Additionally, Pauly et al (2013) argued that both larger and smaller firms possess several favorable and unfavorable charactheristics in promoting CSR practices. However, small businesses, in general, will experience more difficulties than their larger counterparts when engaging in socially responsible action, but they will overcome such constraints (Lepoutre \& Heene, 2006).

Udayasankar (2008) argued that the relationship between firm size and CSR participation is not linear shape in nature. He posits that large sized firms are more likely to have greater involvement in socially responsible activities as they are perceived to be more visible. Small-sized companies may also be equally motivated to achieve legitimacy by doing CSR inititives. Therefore, Udayasankar (2008) proposed the U shape relationship between firm size and CSR practices.

However, Golrida et al (2017) argue that the hypothesis proposed by Udayasankar (2008) may be only applied in developed countries, where the social, economic, and political conditions are more settled as well as such countries which have higher respect for their political, civil rights, international standards, and balance of power. The argument of Udayasankar (2008) that small companies are also actively involved in CSR practices, may be applied in those countries in which social and law enforcement strongly support CSR partices. Many CSR practices require a huge of resources therefore, it needs strong commitment to do it.

By collecting data from listed companies from Indonesian context, which is a developing country, Golrida et al (2017) shows that two perspectives of firm size which are resource access and operating scale, have an inverted U-shape relationship between firm size and CSR participation.
This finding relates to the culture in this country, where companies that have achieved high position and reputation tend to be reckless and do not put importance on CSR participation. For instance, when a company is still small, they might feel the need for CSR initiatives as the way to increase their reputation, but when the company reaches certain position and gets good reputation, they deem that CSR is not that important anymore and will allocate fund to other activities that are considered more important to the firm. However, Golrida et al (2017) can not reveal the inverted U-shape relationship using the third perspective proposed by Udayasankar (2008) since that research use dummy variable to measure visibility.

The present research re-examines the relationship between firm size and CSR from the attribute of visibility which are analyst coverage and news coverage. This research conjectures that visible firms are the ones that are highly covered in news and the ones that are followed by many market analysts. This research contributes to body of knowledge which is macro analysis about CSR practice among countries.

\section{Literature Review and Hypothesis Development}

\section{CSR Definition}

CSR is not a standalone concept. Instead it is embedded with other concepts such as ethics, citizenship, good corporate governance, and others (Sprinkle \& Maines, 2010; Kang et al, 2010; Grosbois, 2012; Zheng et al, 2014; Weber, 2008; Taysir \& Pazarcik, 2013). Besides, CSR is a very wide and contextual concept (Mehar \& Rahat, 2007).

Some researchers for example, refer to philanthropy actions in defining CSR (Wang \& Qian, 2011; Zheng et al, 2014; Brammer \& Millington, 2005; Williams \& Barrett, 2000; Fombrun \& Shanley, 1990), while other focused on environmental and social such as definition published by European Commission (2010).

Due to its nature, CSR has many definitions and the definitions are very conditional as well as dynamic so that it is almost impossible to state a robust definition of CSR. Therefore, debating about the definition of CSR bocomes less important if the focus of discussion is to get a comprehensive understanding about CSR initiatives. Orientation toward CSR participation or involvement reveals more meaningful analysis.

Due to its complex characteristic, a perspective is needed to get a better understanding of CSR definition. Company's perspectives from developing countries, for example, are different from developed countries. Carrol construct (1999) provides a good guidance in explaining the scope of CSR. Carrol (1999) proposed four dimensions of CSR which forms a pyramid construct, consisting of four layers. On the bottom layer is economic dimension responsibility, followed by legal responsibility on the second layer. Ethical responsibility on the third layer and on the top is discretionary 
responsibility or company philanthropy. Economic responsibility is basic responsibility and the most mandatory obligation for all companies, followed by legal responsibility. Not fulfilling these two dimensions of CSR, will cause company in trouble. Ethical responsibility is a responsibility which is not regulated by law, but morally companies have to do the responsibility as it is expected by society. However, the discretionary or philanthropy on the highest layer is purely a voluntary responsibility based on company discretionary or meritocracy.

Carrol construct (1999) is a good reference in determining whether a certain action can be classified as CSR or not. Caroll \& Shabana (2010) argued that Carrol construct is very useful definition because it specifies the firm's economic responsibility as a factor to be considered in CSR, and this becomes very important in thinking about the business people, who in particular, think of their economic performance as something for themselves and for the society. Furthermore, the definition separates legal, ethics and philanthropic categories of CSR, and this helps to do a sharper examination of different motive for each category of socially responsible action.

\section{Countries}

CSR Participation in Developed and Developing

Previous studies tend to analyse CSR practices according to developing and developed countries classification (Beddewela \& Herzig, 2013; Jamali \& mirshak, 2007; Baskin, 2006; Baughn et al, 2007; Cappellin \& Giuliani, 2004; Chapple \& Moon, 2005; Ewing \& Windisch, 2007; Kimber \& Lipton, 2005; Oliviera, 2006; Qu, 2007; Roper \& Weymes, 2007; Welford, 2004). Classification of developing and developed countries in the view of institutional theory (North,1990) generate more homogen country characteristics in analysing CSR practices ( Baughn et al, 2007).

Companies in developing countries practice less CSR compare to those in developed countries due to economic development (Baughn et al.2007). Husted dan Allen(2006) indicated that institutional factors matter in explaining the CSR decision such as governance institutional. Governance institutional in developing countries is generally weaker than those in develped countries (Beddewela \& Herzig, 2013; Jamali \& Mirsha,.2007).

CSR practices in developed countries are mostly done for strategy purpose. Western European and North American countries for example, conduct CSR initiatives to increase the company's performances and reputation, and to fulfill the demand from the government to contribute to society development (Kumar \& Tiwari, 2011; Mullerat, 2013). Gamerschlag et al (2011) found that CSR disclosure in German companies are affected by their visibility, shareholder structure and US stakeholders. A study by Kan (2012) for US companies stated that CSR is important in building their brands, creating innovative products, becoming more sustainable and become more financially stable.

In developing countries however, CSR practices emphasize the importance of helping each other to seek betterment in the communities (Quazi, 2007; Jamali \& Mirshak, 2007; Rajapakse \& Fernando, 2014). Bhattacharyya (2015) findings on Indian companies suggested that firms in India conduct CSR practices based on the strong influence of their cultural ethics and values in their society. Quazi (2007) stated that the principal motivation of Bangladesh firms to engage in CSR activities has stemmed from a sense of their moral obligation to give back to society. Amaeshi (2006) also found that CSR understanding in Nigeria is still largely philanthropic and altruistic.

CSR in the developed countries is more structured. In developed countries, CSR is highly regulated by the government and these regulations serve as the pressure and standard for the companies to implement CSR initiatives. Li et al (2010) stated that institutional factors play an important role in encouraging CSR practices in developed countries.

It is argued that there is lack of a systematic, focused, and institutionalized approach to CSR in developing countries and that the understanding and practice of CSR are still grounded in the context of philanthropic action (Jamali \& mirshak, 2007). In developing countries, a CSR practice is less formalized and is not specifically embedded in any code and standard. In these countries, MNCs representatives play a big role in initiating CSR required by the home country of the MNCs.

Companies in developed countries explore more CSR issues. CSR conducts in developed countries also prioritize the environmental issues as they have high awareness regarding this matter (Kumar \& Tiwari, 2011). For instance, in UK, there are regulations that become the basis for authorized bodies to assess environmental impact of companies, namely Integrated Pollution and Prevention Control (IPPC) Act 1999, which regulated a significantly wider range of pollution sources, and consequently, a larger number of British businesses than any previous legislation (Bichta, 2003). In Japan, the government issued a Basic Environment Law in 1993, Environmental Reporting Guidelines in 2000 and the Environmental Accounting Guidelines in 2005 to ensure that all companies are aware of their tasks to preserve the environment while operating their businesses. Other than that, the government ministries such as Ministry of Environment and Ministry of Health, Labor, and Welfare also issued statutory laws and various guidelines for social and environment responsibilities (Krukowska, 2014).

CSR practices in developing countries often imitate the CSR in developed countries' companies. Bedewella \& Herzig (2013) identified that CSR practices of multinational companies in developing countries are generally initiated by host company from developed countries. In Bangladesh, for example, CSR practices have largely been influenced by the initiatives of MNCs since this country is exposed to global standards (Quazi, 2007). According to Beddewela \& Hezig (2013), MNCs representatives in Sri Lanka play a vital role in pressuring the companies to change their practices to put CSR in higher consideration in conducting their business.

CSR conducted by Indonesia's listed companies lie in the area of philanthropy. CSR is considered as 
social grants and charity issues that may seem obvious to fulfill the demands from stakeholders (Hermawan \& Mulyawan, 2014). Even though in Indonesia, there are such as the Limited Liability Company Law No. 40 year 2007 and Law No. 25 year 2007 that encourages companies which operate their business in the field or industry related to the natural resources must conduct socially and environmentally responsible activities, however, the enforcement of the law seems to be weak.

Trencansky \& Tsaparlidis (2014) collected empirical evidence on Swedish companies and found that the pattern matches the findings of Udayasankar's study (2008). The study reports high levels of CSR participation of small and large firms, while the levels of CSR participation of middle-sized firms were considerable lower (Udayasankar, 2008, p. 172). The study revealed that the U-shaped relationship between firm size and CSR participation exist as a result of lowest motivation to engage in CSR activities by medium-sized companies (Udayasankar, 2008, pp. 167, 172).

\section{Hypothesis Development}

\section{Visibility and CSR Participation}

Motivation for firms to participate in CSR is related to their efforts to enhance visibility and it is explained by legitimacy theory. According to legitimacy theory, legitimacy is an internal interest of firm or companies to operate inherently with the social and environment values to be accepted by the surrounding society (Deegan, 2002). Legitimacy is a general perception that the actions of an entity are desirable and are in alignment with society's values (Suchman, 1995). Increased visibility in the public raises the profile of firms, enhancing their legitimacy in the eyes of the related stakeholders (Mehran \& Peristiani, 2009). Wang (2013) argued that CSR participation is a response towards public pressure as well as media attention or social visibility resulting from major social incidents. The more visible the companies are, the more their actions and decisions are also monitored by many stakeholders, including the media. Therefore, they need to conduct CSR initiatives to gain legitimacy, thus increasing their social reputations by legitimizing their actions. Ramdhony (2015) stated that companies with higher visibility provide more CSR information disclosure to achieve legitimation. Gamerschlag et al (2011) found that German companies' disclosures of all CSR issues are affected by their visibility. Brammer \& Millington (2006) found that visibility found strong support for a positive relationship between organizational visibility and philanthropy. However, according to Lepoutre \& Heene (2006), small companies eventhough facing difficulties in doing CSR will overcome such constraints in order to increase their organizational visibility,

Udayasankar (2008) suggested that large-sized firms are more likely to have greater involvement in socially responsible activities as they are perceived to be more visible, thus, non-participation would bring unfavorable impact to those firms. However, he also stated that small-sized firms might be equally motivated to pursue CSR initiatives, considering CSR as a source for achieving legitimacy, and this legitimacy leads to increasing performance, which serves as an incentive for less visible firms to conduct CSR.

P. Golrida et al. (2017) used company criteria of high and low profile as a proxy of visibility. Their study found that high profile companies tend to practice CSR than that of low profile companies. But the research did not reveal the non linear form of the relationship between firm size and CSR as proposed by Udayasankar (2008). Therefore, hypothesis 1 and hypothesis 2 respectively are stated as follows:

H1: Visibility is positively associated with CSR participation.

$\mathrm{H} 2$ : Visibility is negatively associated with CSR participation

\section{Analyst Coverage}

Analyst coverage is useful for firms to signal information about company performances, and increasing their visibility (Hassan \& Skinner, 2016). The more an analyst follows the company information, the more opportunity for the company to be known publicly or visible publicly.

Several researcherrs previously used analyst coverage as the proxies of visibility. For instance, Jung (2012) analyzed the relationship between visibility and stock return. Chang (2012) used analyst coverage to analyze the relationship between firm visibility, and corporate bond liquidity. Another study explored the impact of S\&P 500 index inclusion on firm visibility (Blease \& Paul, 2003).

Ioannou \& Serafeim (2010) found that firms with higher analyst coverage tend to achieve higher corporate social performance. Firms with more analysts following them will be more visible to the public, thus, those firms conduct CSR to have higher return. However, there are also findings that proposed negative relationship between analyst coverage and CSR participation. The reason for this relationship is that companies have to meet analyst's expectations or estimations towards their financial performance; thus, they will cut back what they deem as unnecessary spending including CSR activities (Adhikari, 2014). Based on the above, hypothesis Ia and hypothesis $2 \mathrm{a}$ are developed as follows:

H1a: Analyst coverage is positively associated with CSR participation.

H2a: Analyst coverage is negatively associated with CSR participation

\section{News Coverage}

Media has become the main source of information regarding current events around the world. Company's events are also recorded in the news, such as company IPO, big and influential transactions, and other positive and negative events of companies can be accessed through the news that are published through the media.

According to the agenda-setting theory, news in media has strong influence towards public opinion. 
Walter Lippmann first wrote the concept of this theory in his 1922 classic, Public Opinion, in which he stated that the news media are a primary source of what we know about the larger world of public affairs (McCombs, 2005). Carroll \& McCombs (2003) stated that news regarding firms' businesses will have impact in forming public's opinion regarding the firms, and the more the company's events are reported in the news, the more visible the company would be. Hence, the higher the frequency of companies' news covered in media, the more visible those companies will be in public.

Blease \& Paul (2003) used news coverage to analyze the relationship between visibility and index inclusion. Fang \& Peress (2009) used number of companies' news in New York Times, USA Today, Wall Street Journal, and Washington Post as the proxy for news coverage and related it to stock return.

There are few literatures that relate news coverage to corporate social responsibility such as the researchers conducted by Ioannou \& Serafeim (2010) and Ekowati (2014). Ekowati (2014) found that the news coverage measured by dummy variable whether the firms publish CSR news or not, has positive relationship towards CSR participation. However, there are also findings that news coverage does not have any relationship towards the CSR (Nur, 2012). There are companies with low news coverage, meaning that it has lower visibility, still conduct good CSR as a tool to increase their reputation.

Therefore, hypothesis $\mathrm{Ib}$ and hypothesis $2 \mathrm{~b}$ are developed as follows:

H1b: News coverage is positively associated with CSR participation

H2b: News coverage is negatively associated with CSR participation

\section{Methodology}

Research Data

This study analyzes the relationship of firm size and CSR participation from the visibility perpective by employing two proxies of visibility which are Analyst Coverage and News Coverage. This research is conducted in Indonesia as a representative of developing countries.

Data of CSR participations are acquired using content analysis method from annual report of companies listed on Indonesian Stock Exchanga in the year of 2012. Table 1 provides sample screening of the companies.

\begin{tabular}{lc}
\multicolumn{2}{c}{ Table 1 Sample Screening } \\
\hline & $\begin{array}{c}\text { Total } \\
\text { companies }\end{array}$ \\
\hline Population & 472 \\
Companies delisted in 2012 & $(26)$ \\
Companies that did not provided relevance information about & $(13)$ \\
CSR & \\
Number of Observations $(\mathrm{N})$ & 433
\end{tabular}

Data of Analyst Coverage and News coverage acquired from Thomson Reuter and www. detik.com on the year of 2012. Considering that CSR data is acquired trough content analysis which take much time to collect the data. Observation period is restricted to one year.

\section{Variable Measurement \\ Corporate Social Responsibility (CSR) \\ Participation}

In this study, Corporate Social Responsibility participation is a dependent variable. The assessment of CSR participation level used in this study is based on the indicators adopted by Sembiring (2005). These indicators are divided into three main categories:

\section{Economic:}

The economic indicators explain an organization's sustainability development initiatives which have an impact on the economic conditions of stakeholders and also the economic performance in the region and international path. The economic indicators contain the business information and 16 indicators are used in this study.

\section{Environment:}

The environment indicators explain an organization's sustainability development initiatives that are related to the ecosystem, nature, water, land and air. The environmental indicators concern about input from natural resources and materials, the result and impact of the output emission, and waste. It also includes the product responsibility performance and 20 indicators are used in this study.

\section{Social:}

The social indicators explain an organization's sustainability development initiatives that affect the social operation. The social indicators consist of the practices of the labors and workers, human rights, and the responsibilities of products that are being produced by the companies in Indonesia. A total of 47 indicators are used in this study.

The analysis is carried out by evaluating the existence of each indicator in company's annual reports. If the item is disclosed in annual report, it is given a score of 1 and if the items are not disclosed in the annual report, it is given a score of 0 .

The measurement formula is:

$$
\text { CSR Participation INDEX } \mathrm{j}=\frac{\sum X i j}{n j}
$$

Notation:

$\mathrm{CSRPj}=$ Corporate Social Responsibility

Participation Index of Company j

$\mathrm{nj}=$ Number of CSR Indicators of company $\mathrm{j}, \mathrm{nj}$

$\leq 83$

$\Sigma \mathrm{Xij}=(1=$ if item $\mathrm{i}$ disclosed and $0=$ if item $\mathrm{i}$ is

not disclosed) 
Thereby, $0 \leq \mathrm{CSRDIj} \leq 1$

\section{Analyst Coverage}

Analyst coverage is measured by the number of analysts who follow the performance of the listed companies and publish the analyst research reports:

Analysts Coverage $=$ Number of Analysts Following the Companies

The data of analyst coverage was extracted from the estimates section provided in Thomson Reuters.

\section{News Coverage}

The variable of news coverage is measured by the frequency of company news covered in media in one year.

News covered in Media

News Coverage $=$ Frequency of Company

We followed several steps to select the media news. First, we used Alexa Rank to find the five best online news portals in Indonesia in the year 2012. Alexa Rank is used because of its credibility and that it is widely used by people to search for best websites all over the world. Furthermore, websites with high Alexa Rank have better image and credibility, as well as more web users (Thakur, 2011). Table 2 provides the top five online news portals for 2012 according to Alexa.com.

\begin{tabular}{lc}
\multicolumn{1}{c}{$\begin{array}{c}\text { Table 2 } \\
\text { Top 5 Online News Portal 2012 }\end{array}$} \\
\hline News portal & Rank \\
\hline Detik.com & 1 \\
Kompas.com & 2 \\
Viva.com & 3 \\
Okezone.com & 4 \\
Tribunnews.com & 5
\end{tabular}

Source: Alexa.com

Second, further selection is done towards the five top online news portals which are shown on table 3. We used two criteria in this selection. In the first criteria, the news website provides the function to sort news published for a particular company on a yearly basis. In the second criteria, the results of news search in the related period must include the amount of news exactly as shown in the stated number of news on the websites to enable the researcher to sort the relevance of the news for each company one by one.

From the first criteria, Viva.com, Okezone.com, and Tribunnews.com were eliminated. For the second criteria, Kompas.com was eliminated because even though the portal has year-sorting feature, the amount of news that are displayed did not match the number of news shown in the searching result. For example, the result showed the result of 500 news of a particular company, but they only display 100 news.
Finally, Detik.com was selected as the source of data for news coverage.

\begin{tabular}{lc}
\multicolumn{1}{c}{$\begin{array}{c}\text { Table 3 } \\
\text { News Coverage Source Selection }\end{array}$} \\
\hline Description & $\begin{array}{c}\text { Online } \\
\text { news } \\
\text { portal }\end{array}$ \\
\hline Alexa's Rank top 5 news portal & 5 \\
$\begin{array}{l}\text { News portals that did not provide feature for the function of year } \\
\text { selection }\end{array}$ & (3) \\
News portal did not show all the news in the observed year & (1) \\
Number of Source $(\mathrm{N})$ & 1 \\
\hline Source: Top 5 online news portals 2012 &
\end{tabular}

\section{Method of Analysis}

The descriptive statistic is used to analyze various statistical calculations values such as minimum, maximum, mean and standard deviation respectively. This research also conducts multiple regression analysis. The regression process was done through Eviews statistical software. The estimation technique used is ordinary least-squares (OLS). This is the most frequently used method since it chooses the coefficient estimation that minimizes the summed squared residuals (Studenmund, 2011). T-test is used to test level of statistical significance of this coefficient estimation and F-stat is used to examine the fit of the overall model. White test is also performed in this regression model in order to avoid the heterokedasticity problem in the proposed model.

The research approach in this study focuses on the multiple regression models.

This research employs several control variables as was done by Golrida et al (2017) which are; total assets (ASSETS), return on asset (ROA), and debt to equity ratio (DER). These three variables have been considered to have influence in determining the CSR participation. Total assets are being used to measure the firm size (Uwalomwa, 2011). ROA also has influence to determine company CSR (Chih, 2010). Additionally, DER also affects corporate social responsibility (Nawaiseh, 2015).

We extracted accounting data, such as net income, total assets, total liabilities, and total shareholders' equity necessary to calculate the control variables from company financial statements that are available at Thomson Reuters.

The regression is conducted separately for models 1 until 3 which exclude control variables. While models 4 until 6 include the regression with control variables (total assets, return on assets, and debt equity ratio).

Regression without control variables:

1. $\mathrm{CSRP}=\alpha+\beta 1 \mathrm{ANALYST}+\beta 2 \mathrm{ANALYST}^{2}+\mathrm{e}$

2. $\operatorname{CSRP}=\alpha+\beta 1$ MEDIA $+\beta 2$ MEDIA $^{2}+\mathrm{e}$

3. $\operatorname{CSRP}=\alpha+\beta 1$ ANALYST $+\beta 2$ ANALYST $^{2}+$ $\beta 3$ MEDIA $+\beta 4$ MEDIA $^{2}+\mathrm{e}$ 
Regression with control variables:

4. $\mathrm{CSR}=\alpha+\beta 1 \mathrm{ANALYST}+\beta 2 \mathrm{ANALYST}^{2}+$ $\beta 3 \mathrm{ASSETS}+\beta 4 \mathrm{ROA}+\beta 5 \mathrm{DER}+\mathrm{e}$

5. CSR $=\alpha+\beta 1$ MEDIA $+\beta 2$ MEDIA $^{2}+\beta 3$ ASSETS + $\beta 4 \mathrm{ROA}+\beta 5 \mathrm{DER}+\mathrm{e}$

6. $\quad$ CSR $=\alpha+\beta 1$ ANALYST $+\beta 2$ MEDIA + $\beta 3$ ANALYST $^{2}+\beta$ MEDIA $^{2}+\beta 6$ ASSETS $+\beta 7$ ROA $^{+}$ $\beta 8 \mathrm{DER}+\mathrm{e}$

Notation:

CSRP $=$ Percentage of CSR participation level;

$\mathrm{A}=$ The estimate of constant term;

$\beta 1 \ldots . \beta 5=$ Estimated of regression coefficient of ANALYST, ANALYST ${ }^{2}$, MEDIA, MEDIA ${ }^{2}$, ASSETS, ROA, DER;

ANALYST $=$ Measure of visibility by the number of analysts following the companies

ANALYST $^{2}=$ Measure of visibility by the number of analysts following the companies quadratic function;

MEDIA = Measure of visibility by the frequency of company news in Detik.com

MEDIA $^{2}=$ Measure of visibility by the frequency of company news in Detik.com quadratic function;

ASSETS = Control variable - natural logarithm of total assets;

ROA = Control variable - Return on assets;

DER $=$ Control Variable - Debt to equity ratio

$\mathrm{e}=$ Error term (permanent mistake estimate

\section{Results and Analysis}

\section{Statistic Descriptive}

Table 4 presents descriptive statistics for all research variables. The findings reveal that only 193 companies of the observed Indonesian Listed companies scored CSR participation above the mean value which was $40.74 \%$. While, the rest of the companies scored below the average of CSR participation value. These figures imply that Indonesian publicly listed companies still have low CSR participation.

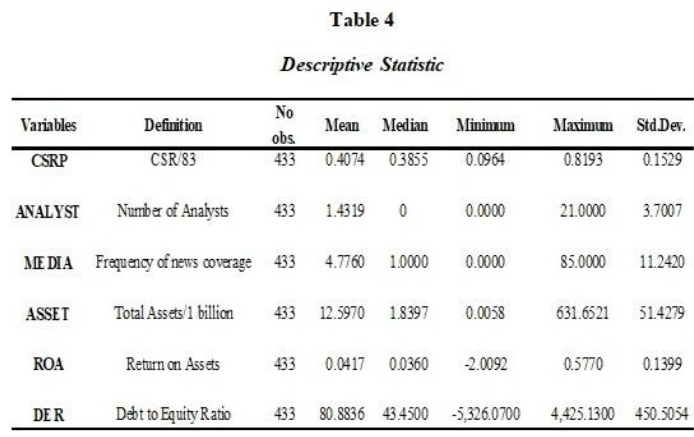

Note: CSR is total percent (\%) of CSR participation, ASSET is the ratio of total assets over 1 billion, ROA is the ratio of return to total assets, and DER is ratio of total liabilities to total equity

Table 5 exhibits the sectors with at least average level of CSR Participation.

Table 5 High CSR Participants

\begin{tabular}{lc}
\hline \multicolumn{1}{c}{ Sector } & $\begin{array}{c}\text { Number of } \\
\text { companies }\end{array}$ \\
\hline Trading, Service, Investment & $32(16.33 \%)$ \\
Basic and Chemical & $28(14.29 \%)$ \\
Real Estate and Construction & $25(12.76 \%)$ \\
Finance & $23(11.73 \%)$ \\
Mining & $22(11.22 \%)$ \\
Other & $18(9.18 \%)$ \\
Consumer Goods & $17(8.67 \%)$ \\
Transport, Infrastructure, and Utility & $16(8.16 \%)$ \\
Agriculture & $12(6.12 \%)$ \\
\cline { 2 - 2 }$\quad$ Total & 193
\end{tabular}

Among the high CSR participants, most of the companies are those that are involved in the well-being of the environment and the welfare of the society, such as Indofood Sukses Makmur tbk, Medco Energi International tbk, Eagle High Plantation, Perusahaan Gas Negara, Sampoerna Agro tbk, and Bank Central Asia tbk.

\section{Analyst Coverage}

Findings reveal that only 89 out of 433 or $20.57 \%$ firms were followed by analysts. Most of publicly listed companies or $79.43 \%$ were not followed by the analysts at all. Therefore, the mean statistic of analyst coverage which amounts to 1.4319 is brought by few companies which were followed by many analysts.

It is interesting to find the fact of those 67 companies that have no analysts following, have more than 50\% CSR participation level. Given that the analyst coverage reflects company visibility, this finding indicates that company of no visibility is motivated to practice CSR.

Among those observed companies, there are 27 firms that have at least 10 analysts following them, such as Bank Central Asia tbk, Semen Indonesia tbk, Astra Agro Lestari tbk, Indofood CBP Sukses Makmur tbk, Kalbe Farma tbk, and Bumi Serpong Damai tbk. The average CSR Participation for these 27 high visible companies is also more than $50 \%$, which is considerably high. 
Table 6

Firnns which followed by Analysts

\begin{tabular}{lc}
\multicolumn{1}{c}{ Sector } & Number firms \\
\hline \multicolumn{1}{c}{ Real Estate and Construction } & 17 \\
Trading, Service, and & 17 \\
Investment & 11 \\
Finance & \\
Transport, Infrastructure, and & 10 \\
Utility & 7 \\
Mining & 9 \\
Consumer Goods & 6 \\
Agriculture & 6 \\
Basic and Chemical & 6 \\
Other & \multicolumn{2}{|c}{69} \\
\cline { 2 - 2 } &
\end{tabular}

Meanwhile, the average CSR panticipation for companies that have less than 10 following analysts is $40 \%$. However, among firms with less than 10 following analysts, $42 \%$ firms perform CSR at an average level of $51 \%$. Table 6 shows the summary of firms that were followed by Analyst.

Table 6 also shows that three top companies that are widely followed by analysts are from real estate and construction, and trading, service and investment, and finance sectors. It is interesting to see that in year 2012, analysts prefer to follow those three sectors. However, it can be explained by the condition of those sectors. PT Mega Capital Indonesia's analysis found the sector of trading, service, and investment has experienced highest growth during 2011-2015 compared to the other sectors (Cakti, 2015). In addition, an analyst from Indo Premier Securities stated that in 2012, stocks in financial and property sectors performed really well and are largely transacted by investors (Viva, 2012). This indicates that market analysts tend to follow stocks of companies that are highly prospective and have positive outlook.

\section{News Coverage}

Even though, the mean of news coverage is 4.7760 , there are 192 companies or $44.34 \%$ from total observed companies that are not covered at all in the news during 2012. However, the CSR practices of 40 companies are above the average. Given the news coverage which reflects company visibility, similar with analyst coverage, this finding also indicates that not visible companies are also motivated to practice CSR. Finding for companies of high news coverage is also similar with what occur in analyst coverage. Furthermore, 55 companies that were covered at least 10 times in the news practice, the CSR participation is more than $50 \%$.
Table 7 Firms with At Least 5 Times News Coverage

\begin{tabular}{lc}
\hline \multicolumn{1}{c}{ Sector } & Number of firms \\
\hline Trading, Service, Investment & 23 \\
Transport, Infrastructure, and & \\
Utility & 17 \\
Real Estate and Construction & 16 \\
Finance & 16 \\
Mining & 11 \\
Consumer Goods & 10 \\
Other & 9 \\
Basic and Chemical & 3 \\
Agriculture & 3 \\
\multicolumn{1}{c}{ Total } & $\mathbf{1 0 8}$ \\
\hline
\end{tabular}

The finding also shows that the average CSR Participation for companies that have been covered less than 10 times is $39 \%$, which almost reaches the average CSR participation level. However, among companies that are covered in news less than 10 times, there are 90 companies which performed CSR at the average level of $54 \%$. These findings reveal the tendency of non linier relationship between news coverage or firm visibility and CSR participation. Table 7 exhibits the sectors with firms that have at least been covered 5 times.

Three top companies that have high news coverage are from trading, service and investment, transport, infrastructure and utility, and real estate and construction sectors respectively. This finding may be explained by the fact that in 2012, government established regulation called Undang-undang (UU) Republik Indonesia No.2/ 2012 and Presidential Regulation called Peraturan Presiden Republik Indonesia (PERPRES RI) No. 71/2012. These regulations about land acquisition for construction and infrastructure projects were expected to bring many benefits for the firms in these industries in building their projects (Mola, 2012). Therefore, in 2012, the firms in these industries launch many new big projects and media covered these events quite intensely. Moreover, along with those projects, several corruption and litigation cases in construction and infrastructure industries are also uncovered and are widely covered by the media. Furthermore, CSR news has low coverage in the news, which might be related to the average low CSR participation of the observed companies. 
Table 8 News Classification

\begin{tabular}{cc}
\hline Category of news & \% \\
\hline Positive & $71 \%$ \\
Negative & $22 \%$ \\
Neutral & $6 \%$ \\
CSR News & $1 \%$ \\
\hline Total & $\mathbf{1 0 0 \%}$ \\
\hline
\end{tabular}

Total news from all observed companies is 2,068 news, which contain $71 \%$ positive news, $22 \%$ negative news, and $6 \%$ neutral news. Interestingly, $1 \%$ news is about companies CSR initiatives and negative CSR news, such as illegal forest fire which damaged the environment.

Table 8 provides all news categories. Positive news mostly covered about increasing financial performance, such as increase in profits, increase in stock price, dividend payment, success in obtaining financing for business operation, business expansion, launch of new products or services, achievements of certain awards, and positive outlook of companies' events. Meanwhile, the negative news include decreasing financial performance, such as decrease in profits, stock suspension, struggle of debt settlement, corruption and other litigation cases, negative outlook for the companies. The neutral news mostly announced the General Meeting of Shareholders.

\section{Regression Results}

The purpose of this research is to capture the empirical evidence of argument of the study conducted by Golrida et al (2017), about the inverted u-shape relationship between firm visibility and CSR participation. This study uses two proxy of visibility which is analyst coverage and news coverage. Table 9 provides the result of the regression.

Model 1 until 3 on table 9 shows the regression without control variables. Model 3 is the regression between CSRP, ANALYST, and MEDIA. These models could explain well the relationship between firm visibility and CSR participation. The coefficient in model 3 indicates that this relationship is reflected in an inverted u-shaped curve. This pattern resulted from the positive and negative correlation between ANALYST and MEDIA variables toward CSR participation.

When the independent variables are regressed separately, the results show that the models are still good enough (fit) to explain the relationship between firm visibility and CSR participation. Model 1 in table 9, shows the result of ANALYST towards CSRP, the coefficient of this model is statistically significant and could be used to explain CSR participation. In model 2, the result of regression between MEDIA and CSRP is also significant and it can be applied to explain the relationship between news coverage and CSR participation. When three control variables are included in the model, the result of regression is still significant, and the model is fit.

Table 9 also provides the regression result for models 4 until 6. In Model 4, we could see that the variable ANALYST still significantly relates to CSR participation even though the significance level decreases a bit. In Model 5, we could see that the variable MEDIA also still significantly relates to CSR participation. The last model, which is Model 6, shows the regression result between ANALYST, MEDIA, ASSETS, ROA, and DER toward CSRP. The regression results show that ANALYST coefficient is statistically significant to explain CSR participation with $99 \%$ confidence level, MEDIA coefficients is also statistically significant to explain CSR participation with $90 \%$ confidence level.

However, the addition of control variables did not necessarily increase the significance of both variables of firm visibility, which are analyst coverage and news coverage. It is interesting to see that, the number of adjusted $\mathrm{R}^{2}$ for model 3 is the highest, with the value of $16.69 \%$ for the adjusted $\mathrm{R}^{2}$. This figure would not be significantly different from the adjusted $\mathrm{R}^{2}$ of the other models, but it could show that the relationship between firm visibility and CSR participation are best explained with this model.

\begin{tabular}{|c|c|c|c|c|c|c|}
\hline & Model1 & Model 2 & Model3 & Model 4 & Model5 & Model 6 \\
\hline ANALYST & $\begin{array}{c}0.03106^{* * *} \\
(0.0000)\end{array}$ & & $\begin{array}{l}0.0268^{* * *} \\
(0.0000)\end{array}$ & $\begin{array}{c}0.03289 * * * \\
(0.0000)\end{array}$ & & $\begin{array}{c}0.02565^{* * *} \\
(0.0001)\end{array}$ \\
\hline ANALYST ${ }^{2}$ & $\begin{array}{c}-0.01133^{* * * *} \\
(0.0005)\end{array}$ & & $\begin{array}{c}-0.0012^{* * *} \\
(0.0004)\end{array}$ & $\begin{array}{l}-0.0014^{* *} \\
(0.0031)\end{array}$ & & $\begin{array}{c}-0.00101^{* *} \\
(0.0158)\end{array}$ \\
\hline MIE DIA & & $\begin{array}{c}0.00911^{* * *} \\
(0.0000)\end{array}$ & $\begin{array}{c}0.00492^{* * *} \\
(0.0051)\end{array}$ & & $\begin{array}{c}0.00904^{* * * *} \\
(0.0000)\end{array}$ & $\begin{array}{c}0.0049 * * * \\
(0.0055)\end{array}$ \\
\hline $\mathrm{MEDIA}^{2}$ & & $\begin{array}{c}-8.53 \times 10^{-5 * 3 * 8} \\
(0.0002)\end{array}$ & $\begin{array}{c}-4.65 \times 10^{-5 *} \\
(0.0505)\end{array}$ & & $\begin{array}{c}-8.36 \times 10^{-5 * 3 * *} \\
(0.0002)\end{array}$ & $\begin{array}{c}-4.43 \times 10^{-58} \\
(0.0517)\end{array}$ \\
\hline ASSE TS & & & & $\begin{array}{l}0.00018 \\
(0.4595)\end{array}$ & $\begin{array}{c}-5.14 \times 10^{-4} \\
(0.9751)\end{array}$ & $\begin{array}{c}-3.11 \times 10^{-5} \\
(0.8935)\end{array}$ \\
\hline ROA & & & & $\begin{array}{l}0.02601 \\
(0.6141)\end{array}$ & $\begin{array}{c}0.0897^{* *} \\
(0.016)\end{array}$ & $\begin{array}{l}0.03385 \\
(0.4715)\end{array}$ \\
\hline DER & & & & $\begin{array}{c}\left.1.27 \times 10^{-5}\right) \\
0.3514\end{array}$ & $\begin{array}{l}5.14 \times 10^{-6} \\
(0.6593)\end{array}$ & $\begin{array}{l}9.31 \times 10^{-6} \\
(0.4603)\end{array}$ \\
\hline $\begin{array}{l}\text { Adqusted } R^{2} \\
\text { F-stat }\end{array}$ & $\begin{array}{c}14.92 \% \\
38.96^{* * *}\end{array}$ & $\begin{array}{c}11.03 \% \\
27.79 * * *\end{array}$ & $\begin{array}{c}16.69 \% \\
22.64 \% *\end{array}$ & $\begin{array}{c}14.66 \% \\
15.84^{* * 8}\end{array}$ & $\begin{array}{c}11.10 \% \\
11.79 * 8 *\end{array}$ & $\begin{array}{c}16.27 \% \\
12.99 * * *\end{array}$ \\
\hline & 433 & 433 & 433 & 433 & 433 & 433 \\
\hline
\end{tabular}

Note: Asterisks indicate significance at $\mathrm{p}<0.10 \quad(*)$, $\mathrm{p}<0.05(* *)$ and $\mathrm{p}<0.01(* * *)$

Since analyst coverage and news coverage are proxies of firm visibility model, the overall regression model provided on table 9 shows that the models are good and can be used to explain the relationship between firm visibility and CSR participation level with the F-stat significance levels within the $99 \%$ confidence level.

Table 10. Correlation Coefficient Matrix

\begin{tabular}{lcccccc}
\hline & CSRP & ANALYST & MEDIA & ASSET & ROA & DER \\
\hline CSRP & 1 & 0.3671267 & 0.298294 & 0.1690098 & 0.096366 & 0.0301188 \\
ANALYST & 0.3671267 & 1 & 0.5586254 & 0.5873098 & 0.1695895 & -0.023768 \\
MEDIA & 0.298294 & 0.5586254 & 1 & 0.5355644 & 0.0334244 & 0.0376499 \\
ASSET & 0.1690098 & 0.5873098 & 0.5355644 & 1 & -0.010568 & 0.0167855 \\
ROA & 0.096366 & 0.1695895 & 0.0334244 & -0.010568 & 1 & -0.034333 \\
DER & 0.0301188 & -0.023768 & 0.0376499 & 0.0167855 & -0.034333 & 1 \\
\hline
\end{tabular}

To show that the regression models in this research are free from the issue of multicollinearity, table 10 presents the correlations between all the independent variables used in this research. The table indicates low 
correlations of each pair of variables, and the result shows that no correlation value is more than 0.8 , meaning that there is no serious multicollinearity problem in this regression model. Furthermore, regression models in this paper applied the White Heterokedasticity Consistent Standard Errors and Covariance. Table 11 shows the heterokedasticity white test result, where the prob. Chi-square value is 0.9795 , indicating that there is no heterokedasticity problem in this regression model since 0.9795 is more than the significance levels of $0.01,0.05$, and 0.1 .

\section{Discussion}

Findings of this study reveal that analyst coverage forms the inverted U- shape relationship with CSR participation. The previous research done by Ioannou \& Serafeim (2010) found that the firms with higher analyst coverage tend to achieve higher corporate social performance, since they need to maintain their reputation. This is also because analysts could serve as external monitoring system towards the company (Chou \& Shiah-Hou, 2007). However, Adhikari (2014) found negative relationship between analyst coverage and CSR participation. The reason is that companies have to meet analyst's expectations or estimations towards their financial performance; thus, they will cut back what they deemed as unnecessary spending including CSR activities.

A finding of this study also reveals that media coverage form inverted U shape relationship with CSR participation. However, the previous research (Kang \& Kim, 2013) found that the relationship between news coverage and CSR performance does not necessarily to be only positive or negative. The effect will most likely be positive only when the tone of the news is negative, while there might be low or no effect when the tone of news is positive. These findings in this study are in accordance to the previous studies, that there is no guarantee of the direction of relationship between firm visibility and CSR participation.

Since analyst coverage and media coverage are both the proxies of visibility, this study indicates that the relationships between firm visibility and CSR participation are reflected in an inverted $\mathrm{u}$-shaped curve. This result is in accordance to Golrida et al. (2017) argument, which proposed inverted u-shape relationship between firm visibility and CSR participation in developing countries.

The findings of this research also strengthen Golrida et al (2017) argument that Udayasankar (2008) hypothesis only applied in developed countries. The previous research done by Trencansky \& Tsaparlidis (2014) also prove that Udayasankar (2008) hypothesis which proposed U-shape relationship between firm size and corporate social responsibility is applied in developed country.
Table 11 Heterokedasticity-White Test

Table 11 Heterokedasticity-White Test

\begin{tabular}{|c|c|c|c|c|}
\hline \multicolumn{5}{|c|}{ Heteroskedasticity Test White } \\
\hline \multirow{2}{*}{$\begin{array}{l}\text { F-statistic } \\
\text { Obs"R-squared } \\
\text { Scaled explained SS }\end{array}$} & $\begin{array}{l}0.546972 \\
19.32928\end{array}$ & \multicolumn{2}{|c|}{$\begin{array}{l}\text { Prob. } F(34,398) \\
\text { Prob. Chi-Square (34) }\end{array}$} & $\begin{array}{l}0.9831 \\
0.9795\end{array}$ \\
\hline & 15.05872 & \multicolumn{2}{|c|}{ Prob. Chi-Square (34) } & 0.9980 \\
\hline \multicolumn{5}{|c|}{$\begin{array}{l}\text { Test Equation: } \\
\text { Dependent Variable: RESID } 2 \\
\text { Method: Least Squares } \\
\text { Date: } 06 / 08 / 16 \text { Time: } 03: 01 \\
\text { Sample: } 1433 \\
\text { Included observations: } 433 \\
\text { Collinear test regressors dropped from specification }\end{array}$} \\
\hline Variable & Coefficient & Std. Error & t-Statistic & Prob. \\
\hline 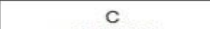 & 0.01 & 0.001942 & 8.95 & 0.0000 \\
\hline ANALYST & 0.005711 & 0.005797 & 0.985249 & 0.3251 \\
\hline ANALYST'^2 & -0.001315 & 0.001438 & -0.914010 & 0.3613 \\
\hline ANALYST*ANALYST2 & 0.000101 & 0.000142 & 0.709741 & 0.4783 \\
\hline ANALYST"MEDIA & 8.79E-05 & 0.000412 & 0.213359 & 0.8312 \\
\hline ANALYST×MEDIA2 & $-2.20 E-06$ & 1.05E-05 & -0.210190 & 0.8336 \\
\hline ANALYST*ASSET & $-1.33 E-05$ & $4.23 E-05$ & -0.313409 & 0.7541 \\
\hline ANALYST*ROA & 0.000432 & 0.025806 & 0.0 & 0.9866 \\
\hline ANALYST=DER & $-6.10 \mathrm{E}-06$ & 2.36E-05 & -0.258243 & 0.7964 \\
\hline ANALYST $2^{\wedge} 2$ & $-3.19 \mathrm{E}-06$ & $4.59 \mathrm{E}-06$ & -0.695 & 0.4871 \\
\hline ANALYST2*MEDIA & $1.40 \mathrm{E}$ & $3.14 \mathrm{E}-05$ & 0.044420 & 0.9646 \\
\hline ANALYST2*MEDIA2 & 1.25E-08 & 7.95E-07 & 0.015747 & 0.9874 \\
\hline
\end{tabular}

The inverted $\mathrm{u}$-shape relationship between firm visibility and CSR shows that when the company is still not too visible, it will increase CSR participation. However, at certain point, when the companies already have high visibility, there is a tendency for the firms to decrease their CSR participation. This situation occurs because of the culture of Indonesian people that become careless or reckless whenever they already achieve the highest position. This causes the firms to feel that there will be unnecessary to conduct CSR initiatives to increase public's awareness of the company, or other specific reasons that results in the decline in their CSR performances.

\section{Conclusion}

This research assessed the relationship between firm size and CSR participation in Indonesia using visibility approach. The analysis was performed using cross-sectional analysis of Indonesian publicly listed companies for the year 2012. Both proxies of visibility, which are the analyst coverage as well as news coverage, have positive and negative relationships with CSR participation. Furthermore, the relationship between those two variables and CSR participation also shows significant relation, forming an inverted $\mathrm{u}$-shaped curve relationship.

The positive correlation happened between low to medium visibility companies and the negative correlation happened between medium to highly visible companies. This result indicates that the companies with medium level of visibility achieve the maximum level of CSR participation. Such indication could mean that the certain small-to-medium visible firms see CSR as a good source to visibility of the companies. Meanwhile, the highly visible firms that are already publicly well known tend to become reckless and feel that it will not be necessary to conduct CSR since they are already in strong position in the market.

The findings of the research show that large sized companies in developing countries do not yet 
exercise their social responsibility optimally. The fact revealed by the study explain the existence of resource curse in developing countries which are rich in natural resourses, as stated by Wiig \& Kolstad (2010). Therefore, the results of the study is a good reference for government of developing countries in evaluating the contribution of large sized especially MNC. In a developing country such as Indonesia currently, there is a trend of utilizing companies's CSR practices to support government programs. The findings of the study are expected to become a good reference in making CSR related policies and regulations in order to make sure that large sized copanies especially MNC fulfill their social responsibility as it should be.

For further research, it may be suggested to reexamine samples from other countries to confirm the form of relationship between size and CSR participation and to enrich macro analysis regarding CSR practices among countries. Researchers may also expand the period of the firms that are being observed so that the results will be able to capture more of the movements of the relationship between firm visibility and CSR participation. By adding more periods to the observations, the results will be more accurate, since companies' CSR behaviors tend to change from time to time Additionally, more countries may be included as the observations to obtain a bigger picture whether the proposed relationship in this paper between firm visibility and CSR participation also applies to other developing countries. Researchers may specify the research to only a certain particular sector or industry to see whether the pattern of relationship would be different between on sector or industry to the others, since firms in certain industry would have different perspective and demands regarding the socially responsible behaviors.

\section{References}

Adhikari, B. K., (2014) Causal effect of analyst following on corporate social responsibility. Alabama.

Amaeshi, K., (2006) Corporate social responsibility (CSR) in Nigeria: Western mimicry or indigenous practices? International Centre for Corporate Social Responsibility Nottingham University.

Baskin, J., (2006) Value, values and sustainability: Corporate responsibility in emerging market companies. Working paper, Cambridge Programme for Industry, October 1.

Baughn, C, Bodie, N, \& McIntosh, J.C., (2007) Corporate social and environmental responsibility in Asian countries and other geographical regions, Corporate Social Responsibility and Environmental Management,14 (4): 189-205.
Bauman, Pauly Dorothée., Christopher, W., Spence, Laura J., Scherer \& Andreas Georg., (2013) Organizing corporate social responsibility in small and large firms: Size matters. Journal of Business Ethics, 115(4): 693-705.

Beddewela, E., \& Hezig, C., (2013) Corporate social reporting by MNCs' subsidiaries in Sri Lanka. Accounting Forum, 37 (2): 135-149.

Bhattacharyya, A., (2015) Corporate social and environmental responsibility in an emerging economy: Through the lens of legitimacy theory. Australian Accounting, Business and Finance Journal, 9 (2): 79-92.

Bichta, C., (2003) Corporate social responsibility: A role in government policy and regulation. Centre for the study of Regulated Industries (CRI).

Blease, John. R. Becker., \& Donna, Paul., (2003) Does index inclusion improve firm visibility and transparancy? Working Paper, Babson College. http://www.fsa.ulaval.ca/nfa2003/papiers/John \%20R.\%20Becker-Blease.pdf

Brammer, S., \& Millington, A., (2006) Firm size, organizational visibility and corporate philanthropy: An empirical analysis. Business Ethics: A European Review, 15 (1): 6-18.

Brammer, S., \& Millington, A., (2005) Corporate reputation and philanthropy: An empirical analysis', Journal of Business Ethics, 61(1): 29-44.

Cakti, G. A., (2015) Sektor Perdagangan, Jasa, dan Investasi Diprediksi Paling Kuat. Retrieved June 2016, from Bisnis.com. http://market.bisnis.com/read/20150105/191/38 7903/sektor-perdagangan-jasa-dan-investasidiprekdiksi-paling-kuat-bulan-ini

Campbell, D., \& Slack, R., (2006) Public visibility as a determinant of the rate of corporate charitable donations, Business Ethics: A European Review, 15 (1): 19-28.

Cappellin, P., \& Giuliani, G., (2004) The political economy of corporate responsibility in Brazil social and environmental dimensions, Programme Paper on Technology, Business and Society (No. 14), United Nations Research Institute for Social Development. 
Caroll, A., \& Shabana, K., (2010) The business case for corporate social responsibility: A review of concepts, research and practice, International Journal of Management Reviews , 12(1): 8510.

Carroll, C. E., \& McCombs, M.. (2003) Agenda-setting effects of business news on the public's images and opinions about major corporations. Corporate Reputation Review, 6 (1): 36-46.

Carroll, Archie. B., (1999) Corporate social responsibility: Evolution of a definitional construct, Business Society 38: 268.

Chang, O, Kedia, S., Wei, J., \& Zhou, X., (2012). Firm visibility and corporate bond liquidity. centerforpbbefr.rutgers.edu

Chapple, W., \& Moon, J., (2005) Corporate social responsibility (CSR) in Asia: A seven country study of CSR website reporting, Business and Society, 44(4): 415-441.

Chih, H. L., et al. (2010) On the determinants of CSR: International evidence on the financial industry. Journal of Business Ethics , 93(1): 115-135.

Chou, R., \& Shiah-Hou, S.R., (2007) Quality of corporate governance, analyst coverage, and analyst forecast error: Do analysts serve as external monitors to managers? Companies Annual Report. (2012). Retrieved from http://www.idx.co.id

Darnall, Nicole., Henriques, I., \& Sadorsky, P., (2009) Adopting proactive environmental strategy: The influence of stakeholders and firm size, Journal of Management Studies, 47 (6): 10721094.

Ebiringa, O. T., Yadirichukwu, Emeh., Chigbu, E.E., \& Ogochukwu, O.J., (2013) Effect of firm size and profitability on corporate social disclosures: The Nigerian oil and gas sector in focus , British Journal of Economics, Management \& Trade, 3(4): 563-574.

Ekowati, L., Prasetyono, \& Wulandari, A., (2014) Pengaruh profitabilitas, likuiditas, growth dan media exposure terhadap pengungkapan tanggungjawab sosial perusahaan (Studi pada perusahaan manufaktur Yang Terdaftar di BEI Tahun 2010-2012). Simposium Nasional Akuntansi XVII, Mataram, Lombok.
Ewing, M., \& Windisch, L. (2007 Contemporary corporate social responsibility in China: An extension of Confucian philosophy, Asian Business and Economics Research Unit Discussion Paper (No. 44) Monash University.

Fang, L., \& Peress, J., (2009) Media coverage and the cross-section of stock returns, Journal of Finance, 64 (5): 2023-2052.

Forbrum, C., \& Shanley, M., (1990) What's in a name? Reputation building and corporate strategy, Academy of Management Journal, 33 (2): 233258.

Frederiksen, L., (2015) What high-visibility firms do to market themselves differently retrieved June 2016, from Hinge Marketing: http://www.hingemarketing.com/blog/story/ne w-rules-of-marketing-what-high-visibilityfirms -do-to-market-themselves-d

Gamerschlag, Ramin., Moller, K., \& Verbeeten, F., (2011) Determinants of voluntary CSR disclosure: Empirical evidence from Germany. Rev Manag Sci, 5(2): 233-262.

Gamrh, Bakr Ali., \& Redhwan Ahmed Al Dhamari ., (2016) Firm characteristics and corporate social responsibility, International Business Management, 10(18): 4283-4291.

Golrida, P. K, Katon, Angesty., \& Joshi, Prem Lal., (2017) A study of inverted U-shape relationship between firm size and corporate social responsibility - the case of Indonesia. Int. J. Accounting, Auditing and Performance Evaluation, 13(3).

Grosbois, Danuta de., (2012) Corporate social responsibility reporting by the global hotel industry: Commitment, initiatives and performance, International Journal of Hospitality Management,31 (3): 896-905.

Hassan, O. A., \& Skinner, F. S., (2016) Analyst coverage: Does the listing location really matter? International Review of Financial Analysis, 46: 227-236.

Hermawan, M., \& Mulyawan, S., (2014) Profitability and corporate social Responsibility: An analysis of Indonesia's listed company, Asia Pacific Journal of Accounting and Finance, 3 (1): $15-31$. 
Husted, Bryan. W., \&. Allen, D. B., (2006) Corporate social responsibility in the multinational enterprise: Strategic and institutional approaches, Journal of International Business Studies, 37(6): 838-849.

Investor Guide., (2010) Analyst coverage, Retrieved June 2016, from http://www.investorguide.com/definition/analy st-coverage.html

Ioannou, I., \& Serafeim, G., (2010) What drives corporate social responsibility? International evidence from social, environmental and governance scores, Harvard Business School. Working Paper 11-016.

Jamali, D., \& Mirshak, R., (2007) Corporate social responsibility (CSR): Theory and practice in a developing country context, Journal of Business Ethics, 72 (3): 243-262.

Jung, M., (2012) Analyst interest, market visibility, and stock returns. Unpublished Working Paper, 2012 - fisher.osu.edu

Kan, W. P., (2012) Corporate social responsibility: A profitable alternative. University of Albany. http://www.albany.edu/honorscollege/files/kan _thesis.pdf

Kang, J., \& Kim, H., (2013) The Impact of media on corporate social responsibility, Conference paper, http://www.apjfs.org/conference/ 2013/cafmFile/11-4.pdf

Kang, Kyung Ho., Lee, L., \& Hu, C., (2010) Impacts of positive and negative corporate social responsibility activities on company performance in the hospitality industry, International Journal of Hospitality Management, 29(1): 72-82.

Kimber, D., \& Lipton, P., (2005) Corporate governance and business ethics in the Asia-Pacific Region, Business \& Society, 44(2):178-210.

Krukowska, M., (2014) Determinants of CSR in Japanese companies, Journal of Management and Business Administration, 22 (4): 39-57.

Kumar, S., \& Tiwari, R., (2011) Corporate social responsibility: Insights into contemporary research, IUP Journal of Corporate Governance, 10 (1): 22-44.
Lepoutre, Jan., \& Heene, A., (2006) Investigating the impact of firm size on small business social responsibility: A critical review, Journal of Business Ethics, 67 (3) :257-273.

Li, Shaomin., Fetscherin, M., Alon, Ilan., Lattemann, C., \& Yeh, K., (2010) Corporate social responsibility in emerging markets: The importance of the governance environment, Management International Review, 50 (5): 635-654.

McCombs, M., (2005) A look at agenda-setting: Past, present, and future, Journalism Studies , 6 (4): 543-557.

McWilliams, A., \& Siegel, D., (2001) Corporate social responsibility: A theory of the firm perspective, Academy of Management Review, 26 (1): 117127.

Mehar, Ayub., \& Rahat,F., (2007) Impact of corporate social responsibility on firm's financial performance, South Asian Journal of Management Sciences, 1(1): 16-24.

Mehran, H., \& Peristiani, S., (2009) Financial visibility and the decision to go private. Federal Reserve Bank of New York Staff Reports No 376.

Mola, T., (2012) Kaleidoskop 2012: Infrastruktur, jalan tol jadi primadona. Retrieved June 2016, from Bisnis.com: http:// industri .bisnis.com/read /20121231/45/112212/kaleidoskop-2012infrastruktur-jalan-tol-jadi-primadona

Montgomery, S., (2014) How to increase your firm's visibility and get more clients, Marketer. https://www.smps.org/wpcontent/uploads/2016/10/August_2014_Market er_How-to-Increase-Your-Firms-Visibilityand-Get-More-Clients.pdf

Mukasa, K., (2015) How do CSR activities influence corporate reputation? Evidence from Korean firms, Journal of Applied Business Research, 31(2): 383-396.

Mullerat, R., (2013) Corporate social responsibility: A European Perspective, The Jean Monnet/Robert Schuman Paper Series, University of Miami, 13 (6): 1-22.

Nawaiseh, M. E., (2015) Influence of firm size and profitability on corporate social responsibility disclosures by banking firms (CSRD): Evidence from Jordan, Journal of Applied Finance \& Banking, 5 (6): 97-111. 
North, D., (1990) Institutions, institutional change and economic performance. Cambridge: Cambridge University Press.

Nur, M., (2012) Analisis Faktor-Faktor yang Mempengaruhi Pengungkapan CSR di Indonesia. Jurnal Nominal , 1 (1). Peraturan Presiden Republik Indonesia No. 71 tahun 2012, Tentang Penyelenggaraan Pengadaan Tanah Bagi Pembangunan Untuk Kepentingan Umum.

Oliviera, J. de., (2006) Corporate citizenship in Latin America: New challenges for business. Journal of Corporate Citizenship, 21: 17-20.

Qu, R., (2007) Effects of government regulations, market orientation and ownership structure on corporate social responsibility in China: An empirical study. International Journal of Management, 24(3): 582-591.

Quazi, A. M., Rahman, Z. \& Keating, B., (2007) A developing country perspective of corporate social responsibility: A test case of Bangladesh, Proceedings of the Australian and New Zealand Marketing Academy Conference: 2789-2795.

Rajapakse, R., \& Fernando, A., (2014) Motives of managers for CSR: $\quad$ Evidence from Sri Lanka. MISG , 1: 78-86.

Ramdhony, D., (2015) Corporate social reporting by Mauritian Banks, International Journal of Accounting and Financial Banking, 5 (2): 5673.

Reverte, C., (2009) Determinants of corporate social responsibility of disclosure ratings by Spanish listed firms, Journal of Business Ethics , 88(2): 351-366.

RHB Securities., (2016) Research, RHB Securities, Indonesia. Retrieved June 2016, from http://rhbinvest.co.id/index.php/tentangkami/research

Roper, J., \& Weymes, E., (2007) Reinstating the collective: A Confucian approach to well-being and social capital development in a globalized economy, Journal of Corporate Citizenship, 26 (Summer): 135-144.

Sembiring, E. R., (2005) Karakteristik perusahaan dan tanggung jawab sosial: Studi empiris pada perusahaan yang tercatat di Bursa efek, Jakarta, Jurnal MAKSI, 6 (1): 69-86.
Shubiri, Faris Nasif., Al-abedallat, Abedalfattah Zuhair., \& Orabi, Marwan Mohammad Abu., (2012) Financial and non financial determinants of corporate social responsibility, Journal of Knowledge Management, Economics and Information Technology, 5(2). Issue 5,ctober, 2012

Sprinkle, Geoffrey B., \& Maines, L. A., (2010) The benefits and costs of corporate social responsibility, Business Horizons, 53(5) : 445453.

Studenmund, A., (2011) Using econometrics. Boston, US: Pearson Education, Inc.

Suchman, M. C., (1995) Managing legitimacy: Strategic and institutional approaches. Academy of Management Journal, 20 (3): 571-610.

Tan, Andreas, Benni, Desmiyawati. \& Liani, Warda., (2016) Determinants of corporate social responsibility disclosure and investor reaction, International Journal of Economics and Financial Issues, 6(S4):11-17.

Taysir, Eyub Aygun., \& Pazarcik, Y., (2013) Business ethics, social responsibility and corporate governance: Does the strategic management field really care about these concepts?, Procedia - Social and Behavioral Sciences, 99: 294-303.

Thakur, A. E., (2011) Quantitative measurement and comparison of effects of various search engine optimization parameters on Alexa Traffic Rank, International Journal of Computer Applications , 26 (5).

Trencansky, D., \& Tsaparlidis, D., (2014) The effects of company's age, size and type of industry on the level of CSR, Umea Universitet http://www.divaportal.org/smash/get/diva2:757602/FULLTEX T01.pdf

Udayasankar, K., (2008) Corporate social responsibility and firm size, Journal of Business Ethics, 83 (2): $167-175$.

Undang-undang Republik Indonesia., (2012) Tentang pengadaan tanah bagi pembangunan untuk kepentingan umum. No 2. file:///C:/Users/FOM/Downloads/UU\%20No\% 202\%20tahun\%202012.pdf 
Uwuigbe, U., (2011) Corporate social responsibility disclosures by environmentally visible corporations: A study of selected firms in Nigeria, European Journal of Business and Management , 3 (9): 9-17.

Viva., (2012) Retrieved 2016, from http://bisnis.news.viva.co.id/news/ read/361573-saham-tiga-sektor-ini-paling-laku

Wall Street Prep Team., (2011) Investment banking vs. equity research. Retrieved June 2016, from https://www.wallstreetprep.com/investmentbanking-vs- equity-research/

Wang, J. L. (2013) The determinants of corporate social responsibility disclosure: Evidence from China, Journal of Applied Business Research, 29 (6): 1833-1847.

Wang, H., \& Qian, C., (2011) Corporate philanthropy and corporate financial perfor-mance: The roles of stakeholder response and political access. Academy of Management Journal, 54 (6): 1159-1181.

Weber, Manuela., (2008) The business case for corporate social responsibility: A company-level measurement approach for CSR, European Management Journal, 26 (4): 247-261.

Welford, R., (2004) Corporate social responsibility in Europe and Asia: Critical elements and best practice , Journal of Corporate Citizenship,13(1): 31-47.

Wiig, Arne., \& Kolstad, I., (2010) Multinational corporations and host country institutions: A case study of CSR activities in Angola, International Business Review, 19 (2): 178190.

Williams, R. J., \& Barrett, J. D., (2000) Corporate philanthropy, criminal activity, and firm reputation: Is there a link?, Journal of Business Ethics, 26 (4): 341-350.

World Business Council for Sustainable Development., (2000) Meeting Changing expectations. Switzerland: WBCSD.

Zheng, Qinqin., Luo, Y., \& Maksimov, V., (2014) Achieving legitimacy through corporate social responsibility: The case of emerging economy firms, Journal of World Business, 50 (3): 687: 15.
Appendix:

\section{List of CSR Disclosure}

\section{Environmental}

1. Polution control, research and development expenditure to alleviate pollution

2. A statement indicating that the operation of companies causes no pollution or fulfill the provisions of the laws and regulations of pollution

3. Statements showing that pollution operation has been or will be reduced

4. Prevention or environmental repairment due to natural resourcess utilization, for example land reclaiming or reforestation

5. Natural resourcess conservation such as recycling glass, iron, oil, water and paper

6. Utilization of recycling material

7. Receiving award relate to environtmental reservation made by company

8. Design facility environmental friendly

9. Contributing in art which embellish environment

10. Contribution in historic buildings restoration

11. Waste recycling

12. Monitoring environment impact

13. Environmental protection

14. Using energy in more efficient way in operations

15. Utilizing recyling goods for producing energy

16. Disclosure of energy saving as a result of products recyling

17. Deliberation of company effort in reducing energy consumption

18. Disclosing the increasing of product efficiency energy

19. Research to support energy efficiency

20. Disclosing company's energy policy

\section{Social}

1. Reducing pollution, irritation, or risk in work environment

2. Promoting safety labor and physical or mental health

3. Disclosing statistic of work accident

4. Comply with regulation of health standard and safety working

5. Receiving award pertaining to safety working

6. Establishment of saftey working committee

7. Participating research to enhance safety working

8. Disclosing labor health service

9. Recruiting or employing woman or people with disabilities

10. Disclosing the percentage / number of woman /people with disabilities in managerial level position 
11. Disclosing the purpose of employing woman/people with disabilities in organization

12. The program to progress labor woman / people with disabilities

13. Training employees through a particular program at work

14. Giving financial support to educate employees

15. Establish training centre for employees

16. Disclosing guidance or councelling towards employee whom are processed for resignation or whose made a mistake

17. Disclosing the plan for housing employees

18. Disclosing recreation facilities

19. Disclosing post employment benefits

20. Disclosing policy relate to salary

21. Disclosing the number of labor in the company

22. Disclosing the managerial level position in company organization

23. Disclosure of staff disposition - where staff placed

24. Disclosing the number of staff, tenure, and their age group

25. Disclosing labor statistics, e g. Sales per labor

26. Disclosing qualification labor who were recruited

27. Disclosing employees stock ownership plan

28. Disclosing other profit sharing plan

29. Disclosing information relate to management relation with employees in improving satisfaction and motivation work

30. Disclosing information relate to job stability and the future of company

31. Inform employees report separately

32. Inform relationship between company and trade union

33. Report employees action and breakdown

34. Disclosing the information of how the actions of labor are negotiated

35. Improvement working conditions in general

36. Provide information of company reorganization that affects employees

37. Provide information and statistic of labor turnover

38. Disclosing the information of product development including the packaging

39. Provide the figure of research and product development expenditure

40. Disclosing the information of research and development project for improving the product

41. Disclosing that the company product meet safety standard

42. Produce product which safer for consumer

43. Participating in research towards company product safety

44. The disclosure of improving cleanliness / health in product processing and setup

45. Disclosure of information on a company product safety
46. The disclosure of product quality information that reflected in receipt of the award

47. Verifiable information that the quality of the product has increased (for example iso 9000 )

\section{Economic}

1. Donation including cash, product, service to support social, education and art activities

2. Part-time employment of the students

3. A sponsor to project community health

4. Help medical research

5. A sponsor for the conference of education , colloquy or an exhibition of art

6. Funding the scholarship program

7. Open facilities to the community

8. Sponsoring a national campaign

9. Support the development of local industry

10. Research towards customer satisfaction

11. Make effort to provide renewable energy

12. Dosclose the impact of infrastucture development

13. Statement that product has complied with government regulation/certified

14. Disclose heallth service for contract labor

15. The disclosure of company purpose / policy in general pertaining to social responsibility to the community

16. Information relating to corporate social responsibility than those mentioned above 